\title{
PERFORMANCE ASSESSMENT OF A PHOTOVOLTAIC SYSTEM FEEDING A DC MOTOR AND CONTROLLED BY A DC-DC CONVERTER
}

\author{
S.S.Shokralla, Dina S. M. Osheba \\ Faculty Of Engineering,Shebin El-Kom- Menoufiya University
}

\begin{abstract}
This paper presents theoretical and experimental analysis of the performance of a photovoltaic system supplying DC loads and controlled by either a cuk or a sepic converter. The nonlinear mathematical model of the system is obtained, considering all operation modes of both converters. A fairly detailed nonlinear simulation was built to assess the performance when system is supplying constant and dynamic loads. Simulation and experimental results are presented illustrating both the steady state and the starting characteristics of the system. The relation between solar irradiation level and the duty ratio for both steady-state and run-up for the cuk and sepic converters have also been given to ensure maximum energy utilization. The results are presented in a comparative form which clearly illustrates that the cuk converter operates over a wider range of irradiation levels. The results also show that with a proper design of photovoltaic generator and careful selection of the dc-dc converter, the performance of a particular application can be optimized by controlling the converter duty ratio.
\end{abstract}

Keywords: Solar Cells, DC-DC Conveter,Cuk Converter, Sepic Converter, Photovoltaic generators, DCMotor

يعرض هذا البحث تحليل نظرى و عملى لآداء منظومة طاقة ضوئية تغذى حمل للتيار المستمر ويتم التحكم فيها عن طريق محوال cuk او الإ محوال

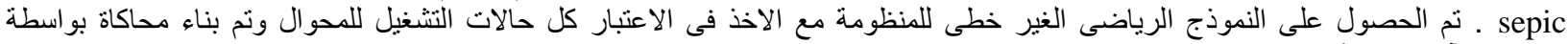

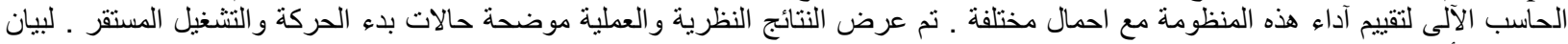

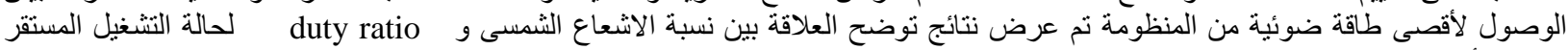

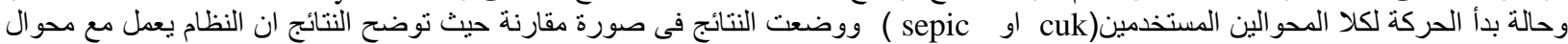

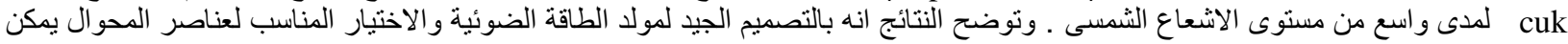
تحسين آداء منظومة الطاقة الضوئية والحصول الأعلى على اقصى قيمة لتحويل الطاقة .

\section{Nomenclature}

A Maximum value of the timing voltage

B Viscous friction coefficient

$C_{1} \quad$ Energy storage/transfer capacitance

$C_{2} \quad$ Capacitance of the filter

E Capacitance Voltage

$f_{s} \quad$ Switching frequency

$i_{m} \quad$ Instantaneous armature current

$i_{1}, i_{2} \quad$ Instantaneous supply and filter currents

J Moment of inertia

$\omega_{\mathrm{m}} \quad$ Motor angular speed

$\mathrm{N}_{s} \quad$ Number of cells in series

$\mathrm{N}_{\mathrm{p}} \quad$ Number of parallel strings
$K_{\mathrm{m}} \quad$ Back e.m.f. coefficient

$\mathrm{L}_{\mathrm{m}}, \mathrm{R}_{\mathrm{m}}$ Armature inductance and resistance

$\mathrm{L}_{1}, \mathrm{r}_{1} \quad$ coil Inductance and resistance

$\mathrm{L}_{2}, \mathrm{r}_{2} \quad$ Filter inductance and resistance

$\mathrm{R}_{\mathrm{f}} \quad$ Field resistance

$\mathrm{T}_{\mathrm{L}} \quad$ Load torque

$\mathrm{v}, \mathrm{V}$ Instantaneous and average supply voltage

$\mathrm{V}_{\mathrm{c}} \quad$ Control voltage

$v_{\mathrm{m}} \quad$ Motor voltage

\section{1- INTRODUCTION}

Engineering Research Journal, Vol. 36, No. 2, April 2013, PP: 101-107 
There is a worldwide agreement on the need to Reduce greenhouse gas emissions. Different policies are implemented both internationally and locally regarding this matter [1,2]. One of the vital components in the achievement of this goal is the intention to provide a high share of energy obtained from renewable sources worldwide. Also, the limited sources of conventional energy and the ever-increasing energy consumption render the search for new sources of energy an urgent matter. It is believed that between the years 2020 and 2030, a major "energy gap" will arise between the required amount of energy and what can be produced from fossil fuels. To resolve this energy gap, new energy sources will be needed. Among these new energy sources, photovoltaic power generation holds particular promise as it is green, unlimited and is available anywhere in the world.

The photovoltaic is considered an electric source for nonspace applications after the oil crisis in 1973. Intensive research plans financed by photovoltaic authorities and incentive programs to encourage the use of photovoltaic energy over the past 40 years led to a substantial reduction in solar cell production cost and enormous increase in solar cell efficiency(2).

There are two major sectors for the use of photovoltaic systems, grid-connected and so-called stand- alone systems. The former delivers power directly to the grid as the dc current from the solar modules is converted into ac by an inverter. The latter supplies power to decentralized of solar cell modules within the photovoltaic array[9]. Also, the maximum power tracking has been achieved by using controlled dc-dc converters [10-12]. Experimental implementation of fuzzy logic control for photovoltaic maximum power tracking is given in reference [13]. The effect of the cell temperature on the performance of a photovoltaic generator feeding series and separately excited DC motors is investigated in [14].

The basic step-down/up switching regulator is known as buck-boost converter, the output voltage of such converter can be higher or lower than the input voltage. The disadvantage of buck -boost converter is that both the input current and the current feeding the output stage are highly discontinuous which requires an external filtering process [15]. Cuk and sepic converters are able to stepup or step-down switching regulators. An advantage of these converters isthat both the input current and the current feeding the output stage are reasonably ripple free [16-19].

This paper presents the performance of a stand-alone photovoltaic system feeding constant and dynamic DC loads and controlled by a dc-dc sepic or cuck converter. The system is also built in the laboratory with a control circuit that has a step up/down capability. To realize the performance of both the cuk and sepic converters experimentally and test the simulation programs, the photovoltaic generator is replaced by a dc source and simulation and experimental results are obtained. Extensive assessment of the performance of the systems and small-scale consumer products. A major use of PV systems being currently developed is in solar home systems, supplying basic electricity demand of rural population in developing countries and many other applications systems in remote areas. Photovoltaic energy has proved to be an economical source of energy in many industrial applications [3]. Photovoltaic (PV) systems are used to drive direct current(DC) motors in many applications such as cooling systems and water pumping systems for irrigation or water supply [4,5]. The photovoltaic system is designed so that the photovoltaic output voltage is suitable for the DC motor. This system is simple and its operation is not expensive as the solar cell generator array is directly connected to the motor load via a suitable coupling [6-7]. Loads such as water pumps are most suitable for solar energy because this type of load does not need continuous operation and water output can be stored easily. This arrangement is very useful and proved to be economical in remote areas, rural villages and desert development.

Starting and steady state performance of different types of DC-motors driving water pumps which are directly connected to a photovoltaic generator are studied in [7]. The performance of pumping system powered by solar cell array have also been predicted theoretically and confirmed experimentally in reference [8]. The maximum power operation has been achieved by interchanging the series parallel connections

photovoltaic system with both converters at different modes of operation is also presented and subsequently discussed. The results are presented in a comparative format illustrating a wider range of the cuck converter operation. This result forms a useful guide in designing stand-alone photovoltaic systems.

\section{2 - DESCRIPTION OF THE SYSTEM}

The schematic diagrams of the two systemsare shown in Figure (1).The system consists of a photovoltaic array connected to a separately excited DC motor via a dc-dc converter. The dc-dc converter used in this study is either a cuk or a sepic converter using one MOSFET. The separately excited DC motor is driving a constant load or a pump load. The dc-dc converter with a variable duty ratio that regulates the power supplied to the motor is either a step-up or step-down converter. An LC filter is connected between the converter and the DC motor to smooth out the voltage input to the motor. The MOSFET is driven by an impulse generator of a linear timing voltage to control the the duty ratio. The duty ratio $(\mathrm{K})$ is defined as the ratio of the ON period of the MOSFET with respect to the whole pulse period. 


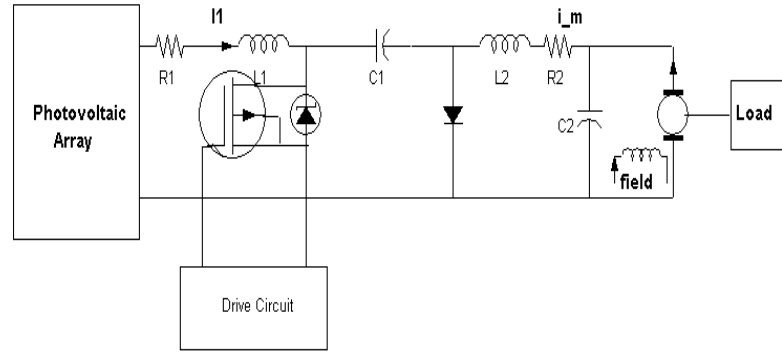

Figure1: Schematic diagram of a cuk converter fed DC motor

\section{SYSTEM MODELING}

\subsection{Mathematical model with a cuck converter}

The system shown in Figure (1) has 4 of operation modes. The nonlinear equations of each mode can be written as follows:

\section{Mode (1)}

In this mode,the MOSFET is turned ON and the current $\mathrm{i}_{1}$ will flow through the loop ${ }^{\mathrm{v}_{-}} \mathrm{L}_{1}, \mathrm{r}_{1}$-MOSFET. The capacitor $\mathbf{c}_{1}$ will discharge into the load circuit and the capacitor $\mathbf{c}_{\text {s. The differential equations in this mode are as }}$ follows:

$$
\begin{aligned}
& d i_{1} / d t=\left(v-i_{1} \cdot r_{1}\right) / L_{1} \\
& d e / d t=-i_{2} / c_{1} \\
& d \omega_{m} / d t=\left(k_{m} \cdot i_{m}-B \cdot \omega_{m}-T_{1}\right) / J \\
& d v_{m} / d t=\left(i_{2}-i_{m}\right) / c_{2} \\
& d i_{2} / d t=\left(e-i_{2} \cdot r_{2}-v_{m}\right) / L_{m}
\end{aligned}
$$

Mode (2)

In this mode,the MOSFET is ON and the capacitor $\mathbf{c}_{1}$ voltage may fall to zero. This depends on the circuit parameters and operating conditions the current $\mathbf{i}_{2}$ will circulates via the diode. The differential equations in this mode are as follows:

$$
\begin{aligned}
& d i_{1} / d t=\left(v-i_{1} \cdot r_{1}\right) / L_{1} \\
& d i_{m} / d t=\left(v_{m}-R_{m} \cdot i_{m}-\right. \\
& \left.K_{m} \cdot \omega_{m}\right) / L_{m} \\
& d \omega_{m} / d t=\left(K_{m} \cdot i_{m}-B \cdot \omega_{m}-T_{1}\right) / J \\
& d v_{m} / d t=\left(i_{2}-i_{m}\right) / c_{2} \\
& d i_{p} / d t=\left(-i_{p} \cdot r_{p}-v_{m}\right) L_{p}
\end{aligned}
$$

Mode (3)

In this mode, the MOSFET is turned off and the capacitor

$\mathbf{C}_{1}$ is charged. The differential equations in this mode are as follows:

$$
\begin{aligned}
& \mathrm{di}_{1} / \mathrm{dt}=\left(\mathrm{v}-\mathrm{i}_{1} \cdot \mathrm{r}_{1}-\mathrm{e}\right) / \mathrm{L}_{1} \\
& \mathrm{de} / \mathrm{dt}=\mathrm{i}_{1} / \mathrm{c}_{1} \\
& \mathrm{di}_{\mathrm{m}} / \mathrm{dt}=\left(\mathrm{v}_{\mathrm{m}}-\mathrm{R}_{\mathrm{m}} \cdot \mathrm{i}_{\mathrm{m}}-\right. \\
& \left.\mathrm{K}_{\mathrm{m}} \cdot \omega_{\mathrm{m}}\right) / \mathrm{L}_{\mathrm{m}} \\
& \mathrm{d} \omega_{\mathrm{m}} / \mathrm{dt}=\left(\mathrm{K}_{\mathrm{m}} \cdot \mathrm{i}_{\mathrm{m}}-\mathrm{B} \cdot \omega_{\mathrm{m}}-\mathrm{T}_{1}\right) / \mathrm{J} \\
& \mathrm{dv}_{\mathrm{m}} / \mathrm{dt}=\left(\mathrm{i}_{2}-\mathrm{i}_{\mathrm{m}}\right) / \mathrm{c}_{2} \\
& \mathrm{di}_{2} / \mathrm{dt}=\left(-\mathrm{i}_{2} \cdot \mathrm{r}_{2}-\mathrm{v}_{\mathrm{m}}\right) \mathrm{L}_{2}
\end{aligned}
$$

Mode (4)

This mode occurs when the supply voltage is quite small and the supply current falls to zero. The differential equations in this mode are as follows:

$$
\begin{aligned}
& \mathrm{d} \omega_{\mathrm{m}} / \mathrm{dt}=\left(\mathrm{K}_{\mathrm{m}} \cdot \mathrm{i}_{\mathrm{m}}-\mathrm{B} \cdot \omega_{\mathrm{m}}-\mathrm{T}_{1}\right) / \mathrm{J} \\
& \mathrm{dv} v_{\mathrm{m}} / \mathrm{dt}=\left(\mathrm{i}_{2}-\mathrm{i}_{\mathrm{m}}\right) / \mathrm{c}_{2}
\end{aligned}
$$

\subsection{Mathematical model with a sepic onverter}

The system shown in Figure (1) is modified and a sepic converter is used to replace the cuck converter. The system now has 4 operation modes which can be described mathematically as follows:

\section{Mode (1)}

In this mode,the Mosfet is ON and the current ${ }_{10}^{\hat{i}_{1}}$ flows in

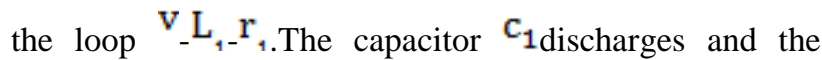
diode $\mathrm{D}$ is reversed biased.The corresponding differential equations in this mode are as follows:

$$
\begin{aligned}
& d i_{1} / d t=\left(v-i_{1} \cdot r_{1}\right) / L_{1} \\
& d i_{2} / d t=\left(v_{c 1}-i_{2} \cdot r_{2}\right) / L_{2} \\
& d v_{c 1} / d t=-i_{1} / c_{1}(25) \\
& d i_{m} / d t=\left(v_{m}-r_{m} \cdot i_{m}-k_{m} \omega_{m}\right) / L_{m} \\
& d \omega_{m} / d t=\left(k_{m} i_{m}-B \cdot \omega_{m}-T_{L}\right) / J \\
& d v_{m} / d t=\left(-i_{2}-i_{m}\right) / c_{2}
\end{aligned}
$$

\section{Mode (2)}

In this mode the Mosfet is off and the diode D is on and $\mathrm{i}_{1}>0$. The corresponding differential equations in this mode are as follows:

$$
\begin{gathered}
d i_{1} / d t=\left(v-i_{1} \cdot r_{1}-v_{c 1}\right) / L_{1} \\
d i_{2} / d t=\left(-i_{2} \cdot r_{2}-v_{m}\right) / L_{2} \\
d v_{c 1} / d t=i_{1} / c_{1} \\
d \omega_{m} / d t=\left(k_{m} i_{m}-B \cdot \omega_{m}-T_{L}\right) / J \\
d v_{m} / d t=\left(i_{2}-i_{m}\right) / c_{2}
\end{gathered}
$$




\section{Mode (3)}

In this mode the Mosfet is off and the diode $\mathrm{D}$ is on and $\mathrm{i}_{1}=0$. The corresponding differential equations in this mode are as follows:

$$
\begin{gathered}
d i_{2} / d t=\left(-i_{2} \cdot r_{2}-v_{m}\right) / L_{2} \\
d i_{m} / d t=\left(v_{m}-r_{m} \cdot i_{m}-k_{m} \omega_{m}\right) / L_{m} \\
d \omega_{m} / d t=\left(k_{m} i_{m}-B \cdot \omega_{m}-T_{L}\right) / J \\
d v_{m} / d t=\left(i_{2}-i_{m}\right) / c_{v}
\end{gathered}
$$

Mode (4)

In this mode the Mosfet is off and the diode D is off and $\mathrm{i}_{1}=\mathrm{i}_{\mathrm{p}}=0$. The corresponding differential equations in this mode are as follows:

$$
\begin{gathered}
d i_{m} / d t=\left(v_{m}-r_{m} \cdot i_{m}-k_{m} \omega_{m}\right) / L_{m} \\
d \omega_{m} / d t=\left(k_{m} i_{m}-B \cdot \omega_{m}-T_{L}\right) / J \\
d v_{m} / d t=\left(-i_{m}\right) / c
\end{gathered}
$$

\subsection{Impulse Generator}

The timing voltage is represented by the equation:

$$
\omega_{\mathrm{a}}=\mathrm{A}\left[1.0-\left(\frac{\mathrm{x}}{\mathrm{T}}\right)\right]
$$

Where $\mathrm{A}$ is the maximum voltage (12 volts), $\mathrm{X}$ is any instant between 0 to $\pi$ in radians, and $T$ is the chopping period in radians and has the form $\mathrm{T}=\omega\left(1 / \mathrm{f}_{\mathrm{s}}\right)[\mathrm{g}]$.

\subsection{Modeling of the Photovoltaic Generator}

The P.V Generator was chosen to have two series modules each of 36 cells, Hence $\mathrm{N}_{s=72}$ cell. The number of branches is taken as $N_{p=6}$ branches to allow for starting current and/or operation at lower irradiation level. The overall voltage of the photovoltaic generator $\mathrm{V}$ is expressed in the following from [8]:

$$
\mathrm{V}=\left(0.0731 * \mathrm{~N}_{\mathrm{s}} * \mathrm{Z}_{1}\right) \quad-\left(0.05 * \mathrm{~N}_{\mathrm{p}} * \mathrm{I}\right)
$$

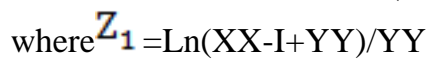

$$
\mathrm{XX}={ }_{\mathrm{ph} *} \mathrm{~N}_{\mathrm{p} *} * \text { irradiation level, } \mathrm{YY}=0.0005 * \mathrm{~N}_{\mathrm{p}}
$$

$\mathrm{V}$ and $\mathrm{I}$ are the average terminal voltage and current from cells, respectively, $\mathrm{I}_{\mathrm{ph}}$ is the photovoltaic current.This current is chosen to be of 0.8 ampere which is proportional to an irradiation level that equals $100 \%\left(1000 \mathrm{watt} / \mathrm{cm}^{2}\right)(3)$, while the open circuit voltage is taken as 0.54 volt. Figure 2 shows the V-I characteristics of the photovoltaic generator used in this study.

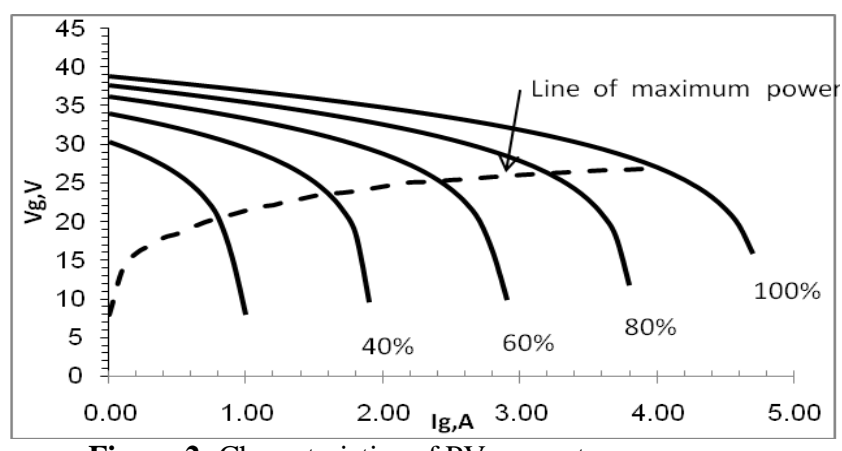

Figure 2: Characteristics of PV generator

\section{SIMULATION AND EXPERIMENTAL RESULTS}

The system was built in the laboratory and a fairly detailed nonlinear simulation was also carried out using a digital computer. The experimental results were obtained after replacing the photovoltaic generator by a DC source. These results were presented in a comparative form with the simulation results. The comparison showed good agreement between experimental and simulation results which substantiate the confidence in the simulation results obtained and presented subsequently concerning the photovoltaic system.

The effect of varying the converter duty ratio for a constant voltage source at different load torques for motor voltage $\left(v_{m}\right)$, motor speed $\left(\omega_{m}\right)$ and motor current $\left(i_{m}\right)$ are shown in Figures (3) for cuk and sepic converters. Also, the starting -up performance with cuk and sepic converters at duty ratio $\mathrm{k}=0.5$ and $63.5 \%$ of full load are shown in Fig 4. These results show a good agreement between experimental and simulation which reveals the validity of the dynamic model used to simulate the system.

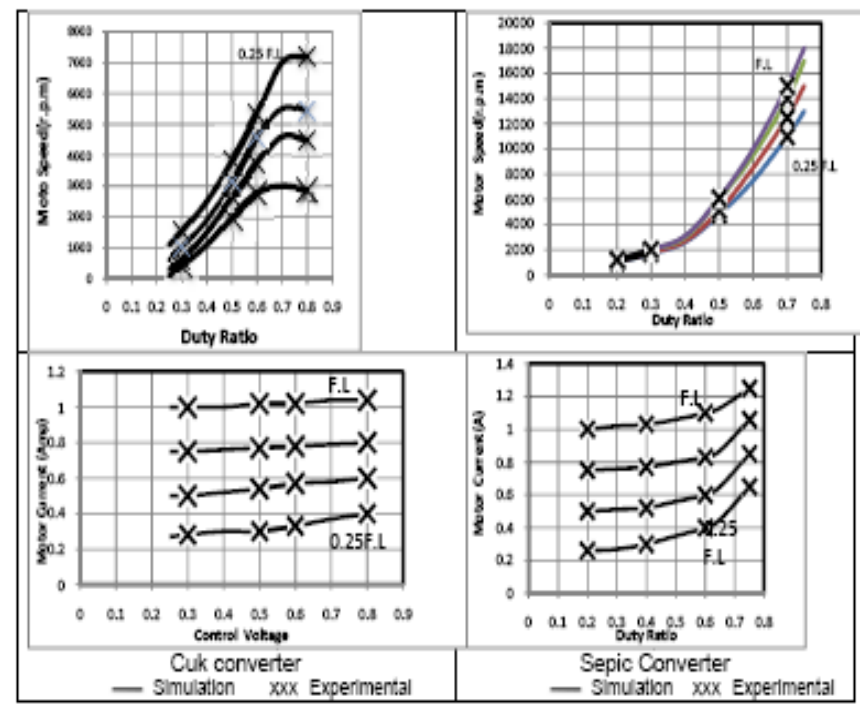

Fig 3: Comparison between simulated and experimental results, Steady state characteristics 


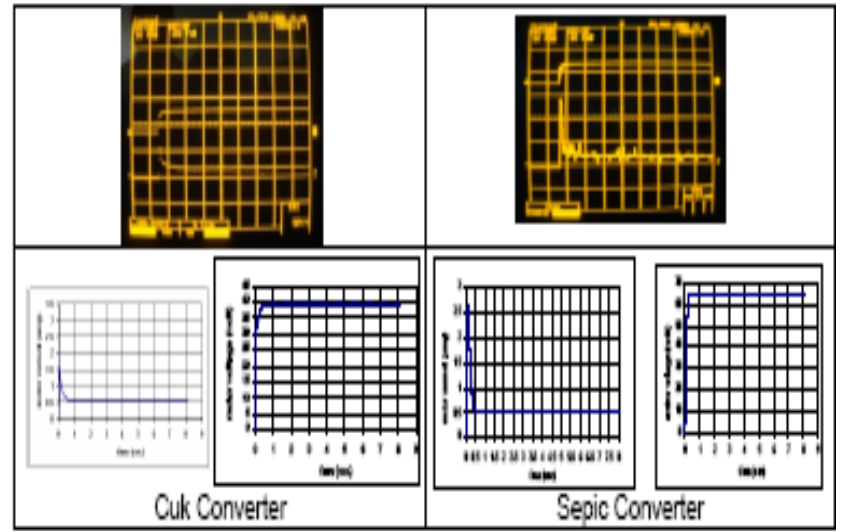

Fig 4 Comparison between simulated and experimental results, transient characteristics

\section{PERFORMANCE OF THE PV SYSTEM}

\subsection{Constant Load}

The effects of varying the irradiation level on motor current, voltage and speed at $50 \%$ of motor load and different values of duty ratio are presented in Figures 5 and 6 when using either cuck or sepic converters. Comparison of these results illustrate clearly that the cuck converter has a wider range of operation with respect to irradiation level and duty cycle for this type of load.

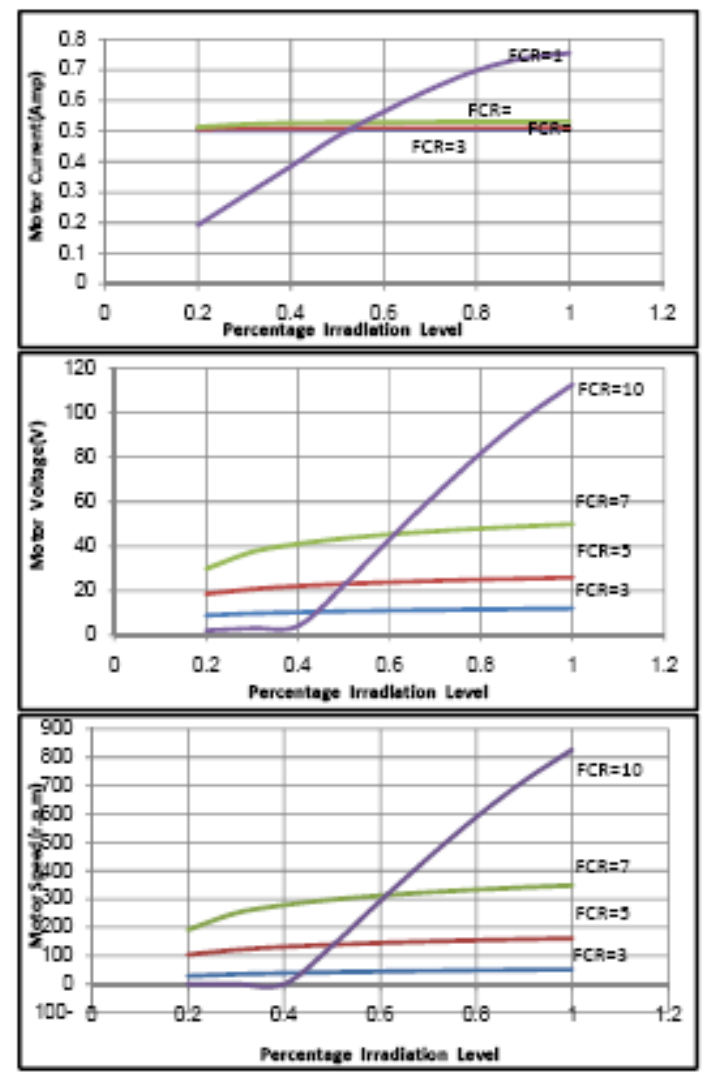

Figure 5 varying solar irradiation levels, cuk converter

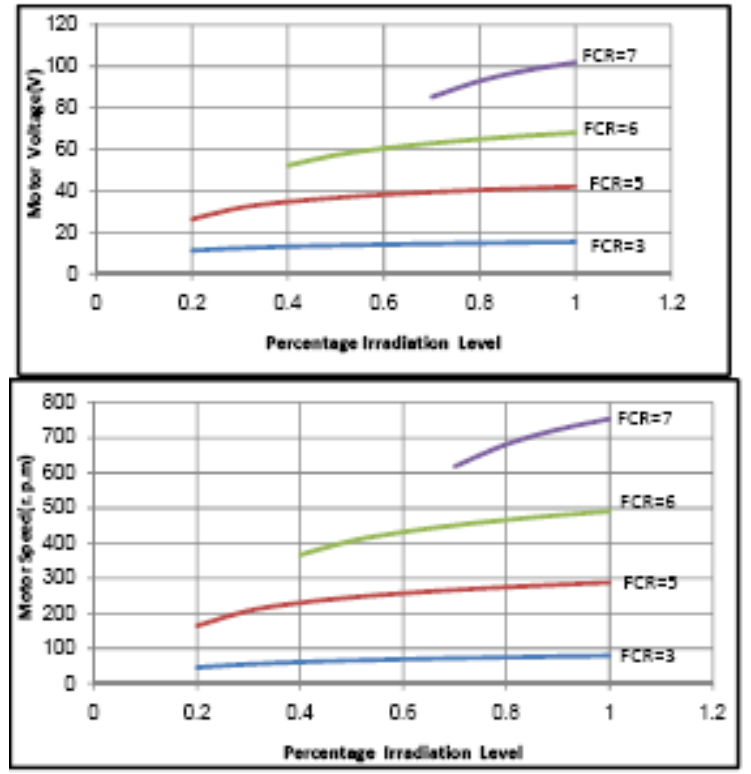

Figure 6 Effect of varying solar irradiation level, sepic converter

\subsection{Pump load}

The motor pump load torque is taken as (7):

$$
\boldsymbol{T}_{\boldsymbol{L}=0.005+0.00004} \boldsymbol{\omega}_{+0.0001} \boldsymbol{\omega}^{\mathbf{1 . 8}}
$$

The effects of varying the irradiation level on motor current, voltage and speed at different values of duty ratio are presented in Figures 7 and 8 when using either cuck or sepic converters. Comparison of these results illustrates clearly that the cuck converter has a wider range of operation with respect to irradiation level and duty cycle in the case of pump load

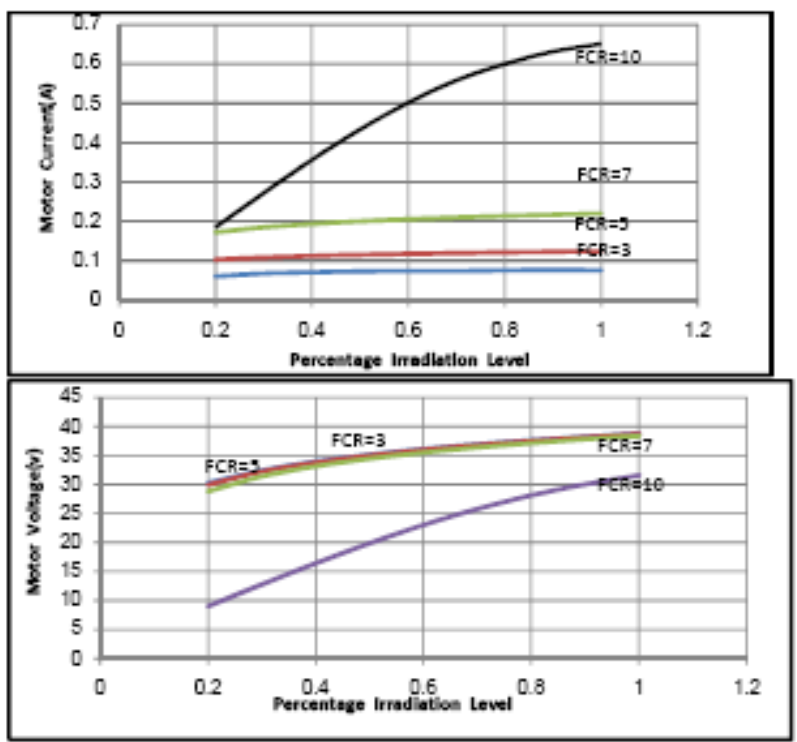

Figure 7 Effect of varying solar irradiation level, cuck converter (Pump load) 

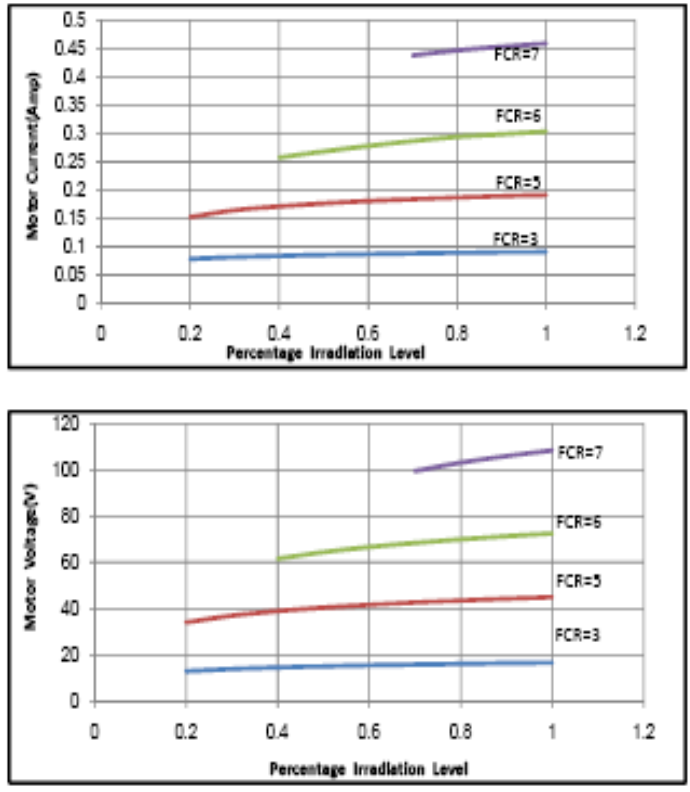

Figure 8 varying solar irradiation levels, sepic

\subsection{Photovoltaic Power}

The output power derived from both photovoltaic systems when feeding a pump load are obtained as a function of the control voltage as shown in Figures 9 and 10. Examining these results illustrates superior performance of the photovoltaic system with cuck converter rather than with sepic converter over a wide range of operation.

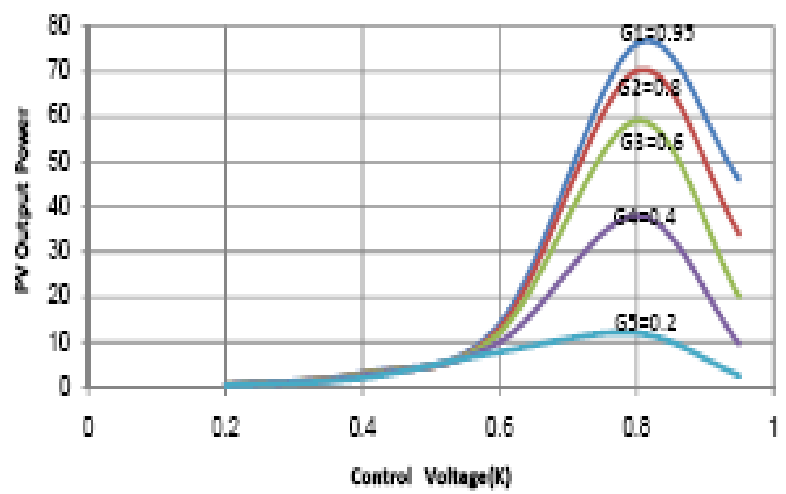

Figure 9 PV Power versus K, cuk converter

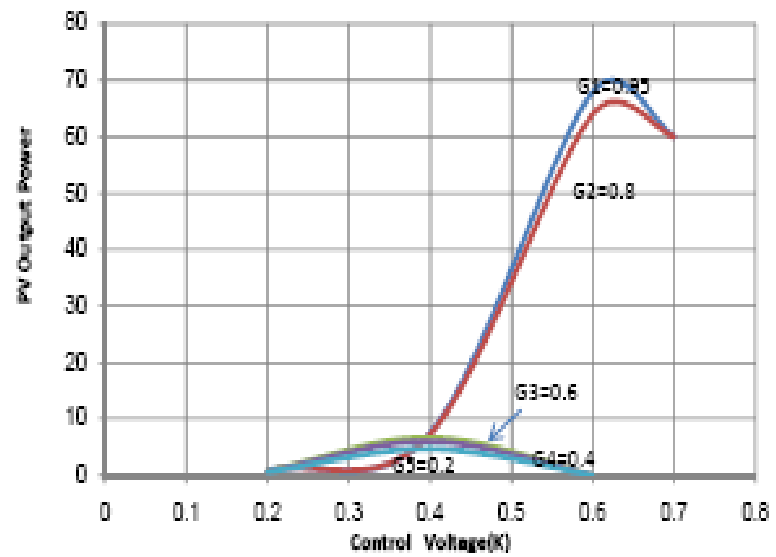

Figure 10 PV Power versus K, sepic

\section{CONCLUSION}

The paper presented steady state and transient performances of static and dynamic loads fed from a photovoltaic system and controlled by dc-dc cuk and sepic converters. The control circuit of the converter was built in the laboratory with a step-up /down capability. Good agreement has been shown between simulation results and those which were obtained experimentally using a dc source. It has been observed that there is a good agreement between the simulation and experimental results for a constant dc supply input voltage.

The results showed that maximum power from a photovoltaic system can be obtained by adjusting the converter duty ratio for all irradiation levels. It has also been observed that the range of operation depends to a large extent on system configuration and the irradiation level. Comparison between cuck and sepic results indicated better system performance of the system with cuck converter with a wider range of operation. The results presented in this paper are of a prime importance to power system engineers, forming a useful guide to design photovoltaic systems in remote areas. 


\section{REFERENCES}

[1] A. Goetzberger and V.U. Hoffmann : Photovoltaic SolarEnergy Generation",ISBN 3540-23676-7SpringerBerlinHeidelbergNew York, 2005

[2] LeonFreris and DavidInfield : Renewable Energy in Power Systems", ISBN978-0-470-01749-4, AJohn Wiley\&Sons, Ltd, Publication,2008

[3] O.Ojo,"Analysis of current source induction motor drive fed from photovoltaic energy source",IEEE Trans, on E.C., Vol.6,No. 1,March 1991,pp.99-106.

[4]J Appelbaum,"Starting and steady state Characteristics of dc Motors powered by solar cell generators", Trans, on E.G.,Vol.1,January, 1989,pp.77-25.

[5] S.Finger and A.Braunste,'The maximum power transfer from nonlinear energy source to an arbitrary load", IEE Proc, Vol. 134,No. 4, 1987,pp.281-287.

[6] J. Appelbaum and B. Singer,'Starting Characteristics Of Permanent Magnet And Series Excited Motors Powered By Solar Cells:Variation With Solar Radiation And Temperature", Electric Machines and power systems,June 1992,pp.173181.

[7] S.S.Eskander,'Proposed Method for Predicting Performance Parameters of pumping system powered by solar cells array “,Proc. Of Sixth Middle East Power System Conference (MEPCON 98),15-17 December 1998, Mansoura, Egypt, pp.699-705.

[8] Z.Zinger and A. Braunstein,'Dynamic Matching of a solar electrical (Photovoltaic) system- An Estimation of Minimum Requirements on the matching system ",IEEE Trans. On Power Apparatus and Systems,Vol. PAS 100, No. 3,March,1981,pp.1189-1192.

[9] S. M.Alghuwainem,'"Steady-State Performance of DC Motors Supplied from Photovoltaic Generators with Step- Up Converter “,IEEE Trans. on E.G.Vol.EC7, No. 2,June 1992,pp.267-272.

[10] M.M.Saied and A.A.Hanafy,"Optimum Design Parameters For A PV Array Coupled to A DC Motor Via A DC-DC Transformer",IEEE Trans. on E.G.Vol.EC6,No. 4 December,1991,pp.593598.

[11] S.M Alghuwainem,"Matching Of a DC motor to A photovoltaic generator Using Step- Up Converter With A Current locked Loop "IEEE Trans.On EC 9,No. 1,March 1994,pp.192-198.

\footnotetext{
A.M.A.Mahmoud,H.M.Mashally,S.A.Kandil, H.EL-Khashab and M.N.F. Nashed,"Experimental Implementaion of FLC For Photovoltaic Maximum Power Tracking",Seventh International Middle East Power System Conference MEPCON 2000,2830 March,2000,Ain Shams University,
}

Egypt,577-583.

[13] I.A.M.AbdelHalim,H.G.Hamed and M.A.AIAhmer,"Effect Of Cell Temperature On The Performance Of A Photovoltaic Generator DC Motor System “,Proc.Of Sixth Middle East Power Systems Conference,MEPCON 92,15-17 December, 1998,Mansoura, Egypt, pp.699-710.

[14] J.MichaelJacob,'Industrial control electronics application and design",Book Prentice Hall, Inc. 1998.

[15] Ned.Mohan,T.M.Undeland and W.P.robbins, "Power electronics:converters Applications and Design",John Wiley and Sons.Inc New York, 1989.

[16] M.A.Ghazey," A Novel DC/DC switching Regulator ", AL-Azher Eng.Third International Conference,December,1993,pp.117-128.

[17] S.S.Shokralla,"A Simplified Approach For Closed -Loop Speed Control of A DC Motor Using AC-DC converter",Alexanderia Eng.Journal,Vol.36,No.2,March 1997,pp.B29B41.

[18] F.M.EL-Khouly,"A simple Fuzzy logic speed controller for a dc motor fed by sepicconverter", Engineering Research Journal,vol.28,No.4 October 2005, pp 343-351.

[19] E.E.M.Rashed and S.S.Shokralla, "PV System fed DC Motor Controlled by Boost converter", Engineering Research bulletin,vol.22,No.2,199,pp 237-259. 